\title{
THE JUDICIARY AND THE CONTRIBUTIONS OF THE BRAZILIAN CODE OF CIVIL PROCEDURE IN LEGAL SECURITY, PREDICTABILITY AND CONSISTENCY OF DECISIONS - MODEL INSPIRED BY THE ENGLISH SYSTEM (JUDICIAL ACCOUNTABILITY)
}

O JUDICIÁRIO E AS CONTRIBUIÇÕES DO CÓDIGO DE PROCESSO CIVIL BRASILEIRO EM SEGURANÇA LEGAL, PREVISIBILIDADE E CONSISTÊNCIA DE DECISÕES - MODELO INSPIRADO PELO SISTEMA INGLES (RESPONSABILIDADE JUDICIAL)

\begin{abstract}
Marcelo Negri Soares
Pós-doutor em Direito pela Universidade Nove de Julho (UNINOVE); Doutor e Mestre em Direito pela Pontifícia Universidade Católica de São Paulo (PUC-SP); Professor do Programa de Pós-Graduação em Direito do Centro Universitário de Maringá (UNICESUMAR); Pesquisador da FAPESP e do ICETI. Email: negri@negrisoares.com.br

Eudes Vitor Bezerra

Pós-doutor em Direito pela Universidade Federal de Santa Catarina (UFSC); Doutor e Mestre em Direito pela Pontifícia Universidade Católica de São Paulo (PUC-SP);

Especialista em Direito Civil e em Processual Civil pela (UNISAL); Graduado e Especialisra em Docência pela Universidade Nove de Julho (UNINOVE); Professor e Coordenador do Curso de Direito da Universidade Nove de Julho (UNINOVE); Email: eudesvitor@uol.com.br

Marcos Kauffman

Doutorando em PhD Programme Coventry University, CU - Inglaterra. Graduado em Direito pela University of Backingham - Inglaterra. Email: marcos.e.kauffman@gmail.com
\end{abstract}

Recebido em: 13/10/2018

Aprovado em: 29/04/2019

\begin{abstract}
Based on the effectiveness of the guarantees of legal certainty, predictability and fairness, this article analyzes the main contributions of the Code of Civil Procedure (Law 13.105 / 2015). With this scope, we introduce initial considerations of some statistics on the increase of the litigation in Brazil and the phenomenon of judicial subjectivism; to explore some of the most relevant mechanisms brought by the CPC that contribute significantly to the construction of a legal environment based on the principles of legal certainty, stability and equality; with clear inspiration in the common law, especially in the English system. This study used the hypothetic-deductive method, based on the literature, the legal system and jurisprudence.
\end{abstract}


Keytwords: Judiciary; Legal Security; Predictability; Decision Uniformity, The Brazilian Code of Civil Procedure 2015.

RESUMO: Com fundamento na efetivação das garantias de segurança jurídica, previsibilidade e equidade, o presente artigo faz uma análise das principais contribuições do Código de Processo Civil (Lei $n^{\circ} 13.105$ / 2015). Com esse escopo, tece-se considerações introdutórias de algumas estatísticas sobre o aumento do contencioso no Brasil e o fenômeno do subjetivismo judicial; para, após, explorar alguns dos mecanismos mais relevantes trazidos pelo CPC que contribuem significativamente para a construção de um ambiente legal baseado nos princípios da segurança jurídica, estabilidade e igualdade; com uma clara inspiração no common law, especialmente no sistema inglês. Este estudo utilizou o método hipotético-dedutivo, com base na literatura, no sistema legal e na jurisprudência.

Palavras-Chave: Judiciário; Segurança jurídica; Previsibilidade; Uniformidade Decisória, o Código de Processo Civil Brasileiro de 2015.

SUMMARY: Introduction; 1. Litigation in Brazil, Explosion of Demands and Legal Uncertainty: a Map of The Judiciary in Numbers; 2 The Important Mechanisms Brought by The New Code of Civil Procedure for Achieving Legal Certainty and The Predictability in Judicial Decisions. 2.1 The Constitutional Procedural Model (or The Constitutional Due Process); 2.2 The Principles of Equality, Legal Certainty and Predictability of Judicial Decisions; 2.3 The English Common Law Model (Judicial Accountability); 2.4 A Conclusion About The Mechanisms Within The CPC. Final Considerations. References.

\section{INTRODUCTION}

In post-modern society, the proliferation of conflicts of interest added to the culture of litigation emerges into a huge demand for judicial services, a phenomenon that is widely recognized by all the operators in the field of law.

The State, as the guarantor of peace in the social environment, is responsible for the resolution of legal crises emanating from interpersonal relations, and to the extent that the judiciary doors are open for claims for any injury or threat to a right, it appears that excessive litigation and extending the performance of this power are prevalent.

The facilitated access to justice and, as a direct result-but not limited to this phenomenonthe problem of the huge demand for adjudication currently assumes large proportions. Faced with this rampant conflict, much has been discussed about the postulates of legal certainty, equality and predictability of judicial decisions, being necessary to search for a greater degree of legal stability, by providing the society with a judicial environment that is safer, isonomic and predictable.

It was against this situation that the New Code of Civil Procedure (Law 13.105/2015) was created-hereinafter, New CPC-widely marked by rationality, simplification and adaptability (or fungibility) and, of course, striving for speed and effectiveness of the process.

According to what was stated in the New $\mathrm{CPC}^{1}$ Explanatory Memorandum, the Code of Civil Procedure of 1973 operated satisfactorily for two decades, however, as of the 1990s, successive reforms have been carried out with the scope of adapting the procedural rules to the

\footnotetext{
${ }^{1}$ Cf. Pre-Project of the New Code of Civil Procedure, p. 12. Available at:

<https://www.senado.gov.br/senado/novocpc/pdf/Anteprojeto.pdf> Accessed on 02.25.19.
} 
changes in the factual-social substrate. It happens that the various procedural changes eventually harmed the overall consistency of the legal system and, in this sense, the loss of the unity of legal rules was a natural consequence, making it imperative to issue a new diploma able to systematize and update all issues under discussion, providing increased functionality and effectiveness.

Moreover, due to the different and incompatible positions in Brazilian courts in the face of the same facts and/or legal standards, sometimes the court rulings can generate a great confusion in society, as well as high levels of legal uncertainty and, in our view, one of the most notable and relevant marks of this New CPC was, therefore, its concern with instability of judicial relations derived from the unpredictability of court decisions, a fact that has been happening for a considerable amount of time, causing a clear and manifest injury to the principles of legal certainty, equality and, why not, the very rule of law.

These key aspects form the topic of this article, since the legal exacerbated dispersion caused by this scenario greatly compromises the unity of law, imposing a look into the eyes of the whole academia in order to better understand the new rules introduced by the New CPC, especially to interpret them in order to provide a better and more consistent (and systemic) applicability.

This article points out to what extent the contributions of the New CPC law allow the appeasement of different social conflicts by a process of the fundamental values of the new order implemented by the 1988 Federal Constitution, given that the guarantee is a constitutional civil procedure, to ensure that fundamental rights and freedoms in a procedural legal relationship should be fostered in all forms of demands and to all citizens.

Therefore, this article, which is based on the hypothetical deductive and inductive method, is structured in two parts. First of all, an analysis of the Judiciary statistics will be provided, revealing a rapid growth of litigation, the high rates of congestion and instability, which will be followed by an examination of the list of legal provisions included in the New CPC, which are understood as genuine coping mechanisms to address the aforementioned problems.

\section{LITIGATION IN BRAZIL, EXPLOSION IN CLAIMS AND LEGAL INSECURITY: A MAP OF THE JUDICIARY IN NUMBERS}

The growing number of legal cases generated by the explosion of litigation that reaches the Brazilian Judiciary daily, according to the official data contained in the Judiciary Report Justice in Numbers 2016, the base year 2015, is approximately 74 million cases proceed through the Brazilian Judiciary, and even decreasing 1.2 million more cases than the entered quantity, the stock increased by 1.9 million cases since 2014 . Initially, it is important to differentiate the number of processes that already exist in the Brazilian Justice. This set of processes, which in 2014 was 100 million and in 2015 increased to 102 million, represents the amount of cases that the judiciary had to deal with during the year, among the already resolved ${ }^{2}$ and unresolved ones. It is not, in any way, the number of processes in progress, because in this concept it is understood that, in fact, it is pending in the judiciary, waiting for a final solution.

The number of processes in the judiciary continues to increase since 2009 , so the cumulative growth for the period was $19.4 \%, 9.6$ million cases more than in the previous year. ${ }^{3}$ Surprisingly,

\footnotetext{
${ }^{2}$ CONSELHO NACIONAL DE JUSTIÇA. Relatório Justiça em Números 2016: ano-base 2016. Brasília: CNJ, 2016. p. 42.

${ }^{3}$ Idem.
} 
it must be noted that even if the judiciary ceased to receive new cases, with the current productivity rates of judges and judiciary staff, it would take about three years of work to clear the cases.

In this alarming scenario, the State Courts are at the top of the list with $69.3 \%$ of the demand and $79.8 \%$ of the processes in the judiciary. The Federal Courts are in the second position with $12.9 \%$ of the total, and the Labor Courts are in the third position with $14.9 \%$ of the total. With regard to the demand, the Federal Courts were the only ones able to reduce the number of pending cases in $2015(-3.7 \%)$, even if subtly. In total, the growth of pending cases was $2.6 \%$ last year and $21.8 \%$ in the period of $2009-2015 .^{4}$

The congestion rate, which constitutes an indicator that measures the percentage of cases that remained with a pending solution to the end of the year in relation to those that were processed (sum of pending and completed) grew in 2015 by approximately $0,5 \%$, bringing the total to $72.2 \%$. ${ }^{5}$

Through the results presented each year, the Justice in Numbers Report has highlighted the negative impact generated by the execution stage in the litigation data from the Brazilian Judiciary, to the extent that it accumulates a high volume of processes and a high congestion rate.

That is why, in the face of all the difficulties, providing effective judicial protection remains a serious problem, since it is useless to apply efforts to quickly resolve the merits of a conflict, if the judiciary fails to deliver, effectively, the litigants.

In order to illustrate this problematic scenario, a simple analysis appeared in the Judiciary collection of almost 74 million cases pending at the end of 2015, among which, more than half (51.9\%) referred to the phase of execution. So, among the pending executions, $82.7 \%$ are in State Courts (about 32 million, representing 53.7\% of their volume); 11.8\% are in the Federal Courts (approximately 4.5 million, representing $50 \%$ of their volume) and $5.5 \%$ are in the Labor Courts (about 2.1 million, representing $41.90 \%$ of their volume). ${ }^{6}$

This scenario is what led to the wording of art. 4th in the New CPC, as the speed should translate into a merit solution in reasonable time, which includes the right to legal satisfaction (e.g. execution of the decision and court orders including the delivery of legal rights). That is why the impact of the execution is significant in the judiciary as a whole, still more noticeable when observing the three main segments of justice. ${ }^{7}$

One of the dangerous aspects of the high level of processual congestion is the fact that-at the State level, and especially at the Federal level-the Government represents the biggest litigant in the country, accounting for $39.26 \%$ of the cases that came to the Courts of first instance and Special Courts, according to data collected between January and October 2011, as revealed by the research Top 100 litigators in the country - 2012, published by the National Council of Justice. According to the report, the public sector and banks are the sectors that lead the list of the biggest litigants, accounting alone for $76 \%$ of the cases in progress. ${ }^{8}$

On the other hand, in the Judiciary, according to the same report of the National Council of Justice, the average time for a process to receive a sentence is 1.5 years (one and a half years), and in the execution phase, this time is more than the double, that is, 4.3 years for the adoption of a sentence in the executive stage.

\footnotetext{
${ }^{4}$ Ibidem, p. 43.

${ }^{5}$ Ibidem, p. 48.

${ }^{6}$ Idem, p. 61.

${ }^{7}$ The original idea of reasonable deadline was born from the Spanish doctrine. (SENDRA, José Vicente Gimeno . El derecho a un proceso sin dilaciones indebidas. Madri: Ed. CGPJ, n. especial I, 1986, p. 47).

${ }^{8}$ CONSELHO NACIONAL DE JUSTIÇA. 100 maiores litigantes 2012. Available at:

<http://www.cnj.jus.br/images/pesquisas-judiciarias/Publicacoes/100_maiores_litigantes.pdf.> Accessed on 02.27 .2019 .
} 
The dataset brought by the National Council of Justice allows us to conclude that the statistics of the Brazilian justice system are alarming, the litigation remains high-with an astronomical collection of 74 million cases in progress-and the need for making decisions and formulating concrete actions to change this situation is latent.

The increasing judicial role, especially regarding the protection of fundamental rights, together with an equally growing "activism"-which, in most cases, eventually culminates in solipsism ${ }^{9}$-contributes significantly to the growth of this scenario, which is already in disarray. Each judge, armed with what they are believed to have (the so-called free motivated conviction), decides in a way, in their own fashion and preference. ${ }^{10}$

As Raphael de Souza Almeida Santos concludes:

The consequences, whether on a scale of 'micro' or 'macro' judicial laws, can already be glimpsed through the increase of appeals lodged with the courts, given the heightened autonomy of judges governed by a pan-principiologism that gloats the procedural methodology established by constitutionally reputable laws, subject to any provisions affront to the rule of democratic rule in that sense. ${ }^{11}$

Lênio Streck, who for a long time focuses on this issue, weaving harsh criticisms of this attitude of judges, said: "... [that] it is not possible to sustain any form of judicial discretion in this historic moment, since discretion is linked to subjectivism (therefore subject-object), averse to the intersubjective paradigm." 12 He continues: "democratic rule of law and discretion are incompatible-and this issue is crucial."13

In regards to the topic of debate in the article, this lack of uniformity of judicial decisions generates intense legal uncertainty-to the extent that it is conceivable and common to see different decisions, to "equal" cases. This lack of uniformity creates consequently a harmful and undesirable level of legal uncertainty, with disregard to the principles of equality, the very legality and consequently it represents a dangerous affront to the democratic rule of law. ${ }^{14}$

\footnotetext{
${ }^{9}$ Decisionism brings, as a bad consequence, the difficulty-not to say impossibility-of jurisdictional control. But not just it. There is also a problem in (the lack of) reasoning in judicial decisions, a problem that the New CPC also tries to solve (art. 489, §1). In an interesting study, Bárbara Gomes Lupetti Batista, after analyzing the judgments of the Court of Justice of the State of Rio de Janeiro, concludes that there is not always a correspondence between the 'real' reasons to decide and the rationale expressed in the judicial decision (Reflexões sobre o dever de fundamentação das decisões judiciais e a imparcialidade judicial: 'o que falar quer dizer' e o que não dizer quer falar? Amazon's Research and Environmental Law, Rondônia, vol. 3, n. 3, 2015, pp. 107-130. Available at: DOI: http://dx.doi.org/10.14690/2317-8442.2015v33169. Accessed on 02.02.2019.

${ }^{10}$ In our opinion, the warning made by Luís Roberto Barroso is correct, by stating that the preservation of the Democratic State of Law (i.e., its non-violation) will depend on the Judiciary, when intervening in a scope that affects the other Powers, to pay attention to legality when involving constitutional precepts(Curso de direito constitucional contemporâneo: os conceitos fundamentais e a construção do novo modelo. São Paulo, Saraiva, 2009, p. 10).

${ }^{11}$ SANTOS, Raphael de Souza Almeida. Entre a técnica e a efetividade: o ativismo judicial como instrumento de garantia dos direitos fundamentais. Amazon's Research and Environmental Law, Rondônia, vol. 1, n. 1, 2013, pp. 7694. Available at: DOI: http://dx.doi.org/10.14690/2317-8442.2013v11101. Acesso em 02.07.2017.

${ }^{12}$ Verdade e Consenso - Constituição, Hermenêutica e Teorias Discursivas. 4. ed, 2. tiragem. São Paulo: Saraiva, 2012 , p. 65.

13 Idem.

14 The report produced by a team of PUC-RS (Judicial demands and the slowness of Civil Justice) also brings the lack of consolidation of the jurisprudence as one of the motivations to litigate and appeal - See: Demandas judiciais e morosidade da Justiça Civil - Relatório Final (PUC-RS), Edital CNJ 01/2009, Porto Alegre, dezembro/2010, p. 7.
} 
It is precisely this scenario outlined above, with high litigation, high processual congestion rates and especially great instability, which highlights the issue that the New CPC was designed to address. This includes effective mechanisms to promote legal certainty and establish an environment permeated by predictability of judicial decisions and, ultimately, respect and integrity to the postulates of equality and legality. The focus on the following sections is placed on an examination on these issues.

\section{THE IMPORTANT MECHANISMS BROUGHT BY THE NEW CODE OF CIVIL PROCEDURE IN ORDER TO PROMOTE ISONOMY, LEGAL SECURITY AND PREDICTABILITY OF JUDICIAL DECISIONS}

The New CPC brought into law new devices that contribute to accelerate trials, but at the same time, it made dramatic improvements in the areas of equality and legal certainty, greatly contributing to definitively trace mechanisms to provide foreseeability of court decisions. Let's look at each of these topics.

\subsection{The Constitutional Procedural Model (Or the Constitutional Due Process)}

It can be said that the New CPC construction process was based, or has as its background, the movement of constitutional alignment of procedures, heavily accented with the Federal Constitution of 1988, which now provides a series of procedural fundamental guarantees. ${ }^{15}{ }^{16}$ It is clear that the art. $1 \mathrm{st}^{17}$ of the New CPC has much more of an educational and expletive effect than an innovative or, in any way, imperative one. This reasoning-that the CPC must comply and be read in light of the Constitution-emanated from the principles of Constitutional supremacy and the Constitution's own normative force.

It is also evident that, by drafting the New CPC, the legislature was concerned quite intensely with the construction and structuring of rules, by making use of principled reasons arising from the constitutional text. This is why it is said that the pillars of the New CPC have the parameters and principles of the Constitution in its foundation.

In comments on the said device (art. 1st, the New CPC), Elpidio Donizetti says that the aforementioned legal precept expresses the constitutionalization of Civil Procedure and, therefore, the positivization of constitutional totalitarianism. In this sense, the author continues:

It is noteworthy that this device is the materialization of neoconstitutionalism features: normativity of the Constitution (normative power), superiority (material) of the Constitution, the centrality of the Constitution (the Constitution is at the center of the legal system), rematerialization of the Constitution (more extended Constitutions dealing with several matters), ubiquity of the Constitution (omnipresence of the Constitution in all branches of law), plural constellation of values (adoption of several non-homogeneous principles), judicial omnipotence (instead of the autonomy of the ordinary legislator), valuation of principles (increased use of weighting). ${ }^{17}$

\footnotetext{
${ }^{15}$ Ver, sobre o tema: GUERRA FILHO, Willis Santiago. Processo Constitucional e Direitos Fundamentais. . ed. São Paulo: Celso Bastos Editor, 2001, passim.

16 Título único ("Das normas fundamentais e da aplicação das normas processuais”) do Livro I, da Parte Geral.

17 Onde se lê: "O processo civil será ordenado, disciplina e interpretado conforme os valores e as normas. Este dispositivo, que inaugura o Novo CPC, encontra-se dentro do Capítulo I, sob a epígrafe "Das normas fundamentais do processo civil".

${ }^{17}$ DONIZETTI, Elpídio. Available at:
} 
The principle brought by the New CPC from an imperative interpretation of its institutes in the light of the Constitution was one of the most striking features of the new Code. ${ }^{18}$ In this senseand as a result-the detachment from formalism and the pursuit of judicial decisions that effectively resolve the dispute and allow the coexistence of a peaceful society also demonstrate its broadest scope to ensure the dignity, personal freedom and true justice.

So it is the so-called constitutional procedural model that seeks to respect the set of constitutional principles to discipline the civil process, starting first with the principle of due process-which could also be called constitutional due process-followed by the principles of equality, legal certainty, access to justice, coherence, reasoned decisions, reasonable length of proceedings, among others.

\subsection{The Principles of Isonomy, of Legal Security and Predictability of Judicial Decisions}

Within this principled matrix used by the New Code mentioned above, it favours the principle of equality, which for the purposes of this paper can be focused on two different perspectives. At first, the equality is analysed from a micro perspective, as a fundamental guarantee of the process and therefore the access to justice: the process then must develop isonomically, maintaining the equality of law amongst the litigants. ${ }^{19}{ }^{20}$

It is not this type of equality that we are referring to. Actually, our approach aims to explore the equality at a macro level, which is to be observed by the process; that is, equal (or equivalent) cases should receive the same (or equivalent) decisions. ${ }^{21}$

Barbosa Moreira, already pointed to this problem, that the fate of litigants depended on the Court (or judge) who would evaluate their demand, and the fact that there may be cases that receive equally, diametrically opposed decisions. Moreira argued that:

The plurality of organs that can be (and often are) to face the same questions of law and thus, to spell out legal arguments in a similar matter. This gives rise to the possibility that, in the same historical moment-with no variation of cultural, political, social, economic conditions, which could account for the discrepancythe same rule of law is understood distinctly, and in similar legal questions, judges apply divergent legal reasonings or even opposite reasonings. Thus, the law is compromised-as such reasoning would not be called into question, on the contrary, due to the homogeneous development of the jurisprudence of various courts-leading to discredit and skepticism about the effectiveness of the judicial guarantees. $^{22}$

\footnotetext{
<http://atualidadesdodireito.com.br/elpidionunes/2012/04/11/expressa-constitucionalizacao-do-direitoprocessualcivil-positivacao-do-\%E2\%80\%9Ctotalitarismo-constitucional\%E2\%80\%9D/> Accessed on: March $16^{\text {th }} 2019$.

${ }^{18}$ FLEXA, Alexandre; MACEDO, Daniel; BASTOS, Fabrício. Novo Código de Processo Civil: temas inéditos, mudanças e supressões - 2. Ed., rev. Ampl. E atual. Salvador: JusPODIVM, 2016, P. 53.

${ }^{19}$ Sob essa perspectiva ver, por todos: Nelson Nery Jr, Princípios do processo na Constituição Federal.

20 . ed. São Paulo: Revista dos Tribunais, pp. 97 e ss.

${ }^{21}$ BARBOSA, Andrea Carla; CANTODARIO, Diego Martinez Fervenza. O incidente de resolução de demandas repetitivas no projeto de Código de Processo Civil: apontamentos iniciais. O Novo Processo Civil Brasileiro (direito em Expectativa): reflexões acerca do projeto do novo Código de Processo Civil. Coord. Luiz Fux. Rio de Janeiro: Forense, 2011, pp. 448-449. Segundo referidos autores: "De um ponto de vista macro, da prestação da tutela jurisdicional, pessoas iguais, envoltas em um mesmo cenário fáticojurídico litigioso, devem receber tratamento igual. O Judiciário não pode ser sede de iniquidades.” (op. cit., p. 449).

22 BARBOSA MOREIRA, José Carlos. Comentários ao Código de Processo Civil. 15 ed. Rio de Janeiro, Forense: 2009, pp. 4-5, Vol. 5.
} 
This problem, however, gained remarkable "visibility in the context of mass litigation, where, despite the efforts, reproduces solutions engineered for cases that are not always the same." ${ }^{23}$ And it is precisely in this context that "the unity in the application of the law and consistency of service provision by the judiciary demand the creation of mechanisms aimed at the standardization of the jurisprudence". ${ }^{24}$

On the other hand, in the same environment, the New CPC stands out, holding the primacy of legal certainty in the midst of the relations between litigants, a value that the democratic rule of law considers one of its fundamental elements. That is, there is the inexorable need to bring stability and clarity to the social and legal relations, so that the establishment of order in social life is one of the main objectives of the law as a whole.

Thus, it is clear that the achievement of the principles above in a society in which chaos is the norm, with no legal certainty glimpsed in interpersonal relations would not be possible. As pointed out by Humberto Theodoro Junior in a relevant lesson about the importance of legal certainty, there are two main directions regarding the interpretation of the aforementioned principle. First, legal certainty derives from the predictability of decisions to be adopted by the bodies that will have to apply the rules and regulations. The second meaning is relative to security, which can be viewed in the stability of the definitive legal relationships. ${ }^{25}$

This article is concerned with the first point, to the extent that the New CPC sought, with clear clarity, to provide safeguarding for legal certainty through foreseeability of court judgments, by providing a list of devices seeking to honor the guarantee and the stability of the legal system as a whole and, ultimately, the unit of law.

In this context, Arruda Alvim explains that:

Another important point to be stressed in the New CPC is the extreme caution of the Code in the emphasis and maintenance of a good standard of legal security, understood as predictability of what is expected to be decided and the jurisprudential stability. It tried, as we will see, to further encourage the uniformity of jurisprudence and its stability ...". ${ }^{26}$ (Italics are from the original)

That said, the New CPC has the values of equality and, equally, of legal certainty, as its strategic orientation, striving for an operative stability that can only be achieved with the construction of a rational system, which does not admit the coexistence-of simultaneous, in the same historical, political and social time-of several coexisting understandings of the meaning of the same law.

\footnotetext{
${ }^{23}$ BARBOSA, Andrea Carla; CANTOARIO, Diego Martinez Fervenza. O incidente de resolução de demandas repetitivas no projeto de Código de Processo Civil: apontamentos iniciais. O Novo Processo Civil Brasileiro (direito em Expectativa): reflexões acerca do projeto do novo Código de Processo Civil. Coord. Luiz Fux. Rio de Janeiro: Forense, 2011, p. 450.

${ }^{24}$ Idem.

${ }^{25}$ THEODORO JÚNIOR, Humberto. Onda reformista do Direito Positivo e suas implicações com o princípio da segurança jurídica: Revista Brasileira de Estudos Políticos, nº 89, jan-jun 2004.

${ }^{26}$ ARRUDA ALVIM, José Manoel de. Novo Contencioso Cível no CPC/2015. São Paulo: Revista dos Tribunais, 2016, pp. 23-24.
} 
Teresa Arruda Alvim Wambier and Bruno Dantas explained that "The need for uniformity is innate to the idea of a legal system, which is essential to the creation of predictability, legal certainty and equal treatment of individual ${ }^{27}$. Furthermore, discussing now the principle of legality:

Underlying the need for respecting the precedents of civil law, the principle of legality and equality, both akin to the idea of rule of law, the most visible feature is that society needs to 'know the rules of the game before starting to play.'

(...)

So the legality only has practical sense if implemented under the principle of equality. If there are several rules to decide the same case, how would you know in advance which rules would be applied by the courts in a particular case? It is useless for the law to be the same for all, if the courts can interpret it in different ways and surprise the litigants." 28

Summarizing the key points, didactically established in the Article 926: "The courts must standardize their jurisprudence and keep it stable, fair and consistent." Nothing could be more correct. The question that arises, however, is how to achieve these goals? The New CPC makes it for a diverse range of institutions.

In the foreground, it introduces a binding precedent system (mandatory), as can be read in the Article 927, section and paragraphs, the vertical application of the jurisprudence. ${ }^{29}$ But not only this, the New CPC provides this through the prediction of the Incident of Repetitive Demands Resolution (IRDR) and the Assumption of Jurisdiction, and systematizes-providing a greater binding or obligatory respect for the lower courts-the so-called repetitive (special and extraordinary) decisions.

According to Alexandre Camera:

It is essential to preserve the legal certainty and equality that similar cases receive equal decisions. And this can only be achieved when the judges and courts respect not only the decisions of the courts that may be higher (vertical effectiveness), but also their own decisions (horizontal effectiveness). For the Code of Civil Procedure seeks to regulate how

\footnotetext{
${ }^{27}$ Recurso especial, recurso extraordinário e a nova função dos tribunais superiores no direito brasileiro - de acordo com o CPC de 2015 e a Lei 13.256/2016, 3. ed. São Paulo: Revista dos Tribunais, 2016, p. 175 (os itálicos são do original).

${ }^{28}$ Recurso especial, recurso extraordinário e a nova função dos tribunais superiores no direito brasileiro - de acordo com o CPC de 2015 e a Lei 13.256/2016, 3. ed. São Paulo: Revista dos Tribunais, 2016, pp. 178-179 (itálicos do original).

${ }^{29}$ A bem da verdade, essa verticalização da jurisprudência dos Tribunais Superiores, e o próprio "valor" que se há de emprestar a ela não é novidade do CPC/2015. No Código anterior, por exemplo, conferia-se ao juiz de primeiro grau a possibilidade de inadmitir o recurso de apelação quando a sentença estivesse em conformidade com súmula do Superior Tribunal de Justiça ou do Supremo Tribunal Federal (art. 518, parágrafo primeiro). Na mesma linha, vinha o art. 557, com a seguinte redação: "O relator negará seguimento a recurso manifestamente inadmissível, improcedente, prejudicado ou em confronto com súmula ou com jurisprudência dominante do respectivo tribunal, do Supremo Tribunal Federal, ou de Tribunal Superior". Além disso, menciona-se a inclusão da repercussão geral pela Emenda Constitucional 45/2004 e o sistema de julgamento de recursos extraordinários repetitivos - e essa hipótese é bastante emblemática, por seus efeitos -, tal como contemplada pela Lei n. 11.418, de 2006, que acresceu o art. 543B, ao CPC/1973. Esse regime de julgamento por amostragem foi, mais tarde, incorporado ao recurso especial, mediante a Lei n. 11.672, de 2008, acrescentando o art. 543-C ao revogado Código de Processo. Podemos citar ainda outros exemplos, dessa valorização da 'jurisprudência' firmada nos arts. 285-A e 544, parágrafos terceiro e quarto, ambos do mesmo Código de 1973.Ver, por todos, sobre o tema: Teresa Arruda Alvim Wambier. Estabilidade e adaptabilidade como objetivos do direito: civil law e common law. Revista de Processo, v. 172, São Paulo: Revista dos Tribunais, jun./2009, p. 132-ss.
} 
the previous exercise binding effect, which is needed in the search for a more isonomic and, therefore, more democratic process. ${ }^{30}$

Thus, it focuses on the case of law, in clear approximation with the common law systems. The reiterated behaviour of the superior courts and their consolidated understandings gain greater relevance, and eventually serve as a precedent to the rest of the judiciary and, why not, for society as a whole.

\subsection{The English Common Law Model - Judicial Accountability}

In England and Wales, both individual judges and the judiciary as a branch of the State are subject to a number of forms of accountability that are not incompatible with their individual and institutional independence. The notion of Judicial Accountability in the English Common Law system was once seen as part of a command and control relationship. Today, however, the concept is more fluid including a number of practices that explain, justify and open the area in question to public dialogue and scrutiny. The difference is captured by Professor Vernon.

Bogdanor's distinction between "sacrificial" and "explanatory" accountability. ${ }^{30}$ The former involves taking the blame for what goes wrong, and forfeiting one's job, if something goes seriously wrong. The latter involves giving an account of stewardship, for instance, in the case of ministers to Parliament and to the electorate.

It is generally accepted that, except according to the Act of Settlement 1701, judges cannot be held accountable either to Parliament or to the executive in the sacrificial sense and that they cannot be externally accountable for their decisions. ${ }^{31}$

Such accountability would be incompatible with the principle of the independency of the judiciary. But, except for the House of Lords, they are held to account by higher courts hearing appeals, and (except where the issue belongs to EU law-whilst the UK remains as part of the EU) it is open to Parliament to legislate in order to reverse the effect of a decision or body of doctrine.

Moreover, the duty to give reasons for decisions is a clear example of "explanatory" accountability, which assists transparency and scrutiny by the other branches of the State and the public (as well as facilitating appeals). In relation to the judiciary of England and Wales, it is suggested that the position is that there is a number of practices that can be understood as forms of accountability in one or other of the senses of this term. These forms of accountability are:

i- Internal accountability to more senior judges or courts through (a) the system of appeals against judicial decisions, and (b) procedures for dealing with complaints about the conduct of judges;

ii- External accountability to the public through amenability to scrutiny in particular by the media, but more widely by civil society;

iii- Accountability to the executive branch of the State (the Government); and iv- Accountability to the legislative branch of the State (Parliament). ${ }^{32}$

\footnotetext{
${ }^{30}$ Bogdanor, Parliament and the Judiciary: The Problem of Accountability, (Third Sunningdale Accountability Lecture 2006); Le Sueur in Independence, Accountability and the Judiciary (BIICL 2006), eds Andeanas and Fairgrieve, 49-50.

${ }^{31}$ Book Reviews: Controlling Administrative Power: An Historical Comparison - Gageler, Stephen. The Cambridge Law Journal; Cambridge Vol. 76, Iss. 2, (Jul 2017): 430-433.

32 https://www.judiciary.uk/wp-content/uploads/JCO/Documents/Consultations/accountability.pdf
} 
These forms of accountability overlap. For instance, the appeal and complaint processes provide both internal and public accountability, and giving evidence to legislative committees provides direct accountability to Parliament and indirect accountability to the public.

In regards to the focus of this study, the key accountability areas for discussion are, in the first place, the internal accountability to "the judiciary" and, in the second place, the accountability to the public. Each of these areas will be discussed at a time.

Internal accountability manifests in the daily life of individual judges in the sense that their decisions are subject to the system of judicial precedents, as well as to appeal, and other judges are responsible for allocating cases to them, individual judges are accountable to senior judges or judges holding positions of responsibility. As for the conduct of judges, a working group established by the Judges' Council published a Guide to Judicial Conduct in October, $2004 .{ }^{33}$ This seeks to provide guidance on matters such as; impartiality, integrity, competence and diligence, personal relationships and perceived bias and activities outside the court.

The responsibilities of the Heads of Division, Presiding, Resident and Family Liaison and Chancery Supervision Judges, and judges in charge of a particular jurisdiction, are designed to assist in the effective management of judicial work. ${ }^{34}$

They must be exercised with due regard to the importance of the need to respect the independency of individual judges in relation to the decisions before them. This means, for example, that they cannot tell another judge how to decide a case.

Decisions as to listing and allocation are designed to ensure that cases are heard by an appropriate judge and that the available judiciary is fully and effectively deployed within the resources provided by the executive branch of the State. We must observe, however, that one of the guarantees of independency under Article 6 of the European Convention of Human Rights, reflecting underlying common law principle, is that judges must be free from outside instructions or pressure from other members of the court or the judiciary. This limits the extent and form of discipline to which a judge may be subjected to.

In terms of accountability to the public, it is manifested in the form of the formal processes of court proceedings, which provide accountability to the public, enabling scrutiny of the work of individual judges. As a general rule, court proceedings and the decisions of judges are made in public. Decisions must be reasoned, and are subject to comment, often robust comment, by the media and other commentators. The quality that includes consistency of individual decisions is also subject to control in the form of appeal to higher courts against alleged errors. This identification and correction of error by appeal courts is also public and reasoned.

It is clear that the system of judicial precedent is a very important aspect of judiciary accountability, both internally and to the public. The system of judicial precedent refers to the fact that in common law a judgment of a court of law is cited as an authority for deciding a similar set of facts; a case that serves as authority for the legal principle embodied in its decision. The common law has been developed by broadening down from precedent to precedent.

In this manner, a judicial precedent is a decision of the court used as a source for future decision-making. This is also known as the Principe of Stare Decisis (to stand upon decisions) and by which precedents are authoritative and binding and must be followed. Thus, by judging a case, the judge will set out the facts of the case, state the law applicable to the facts and then provide his

\footnotetext{
${ }^{33}$ Available at the Judiciary website - https://www.judiciary.uk

${ }^{34}$ See The Responsibilities of Resident Judges and Designated Civil and Family Judges

https://www.judiciary.uk/about-the-judiciary/the-judiciary-the-government-and-the-constitution/how-the-judiciaryis-governed/leadership-responsibilities/ Available on the judiciary’s website)
} 
or her decision. It is only the ratio decidendi (the legal reasoning or ground for the judicial decision) which is binding on later courts under the system of judicial precedent. As such, any observations made by the judge on a legal question suggested by the case before him or her but not arising in such a manner as requiring a decision is known as obiter dictum (a saying, by the way).

There may be several reasons for a decision provided by the judge in any given judgment and one must not assume that a reason can be regarded as 'obiter' because some other 'ratio' has been provided. Thus, it is not always easy to distinguish ratio decidendi from obiter dictum when evaluating the effects of a particular decision.

As a rule, decisions of a superior court are absolutely binding on subsequent inferior courts. However, certain of the superior courts regard themselves as bound by their own decisions whilst others do not, the special rules are:

i- Decisions of the House of Lords bind all other courts but the House does not regard itself as strictly bound by its previous decisions, for example, in Murphy v Brentwood District Council (1990) ${ }^{35}$ (the House elected to overrule its earlier decision in Anns v London Borough of Merton (1978) ${ }^{36}$ on the issue of a local authority's liability in negligence to future purchasers of property.

ii- The Court of Appeal, Civil Division, holds itself bound by its previous decisions: Young v Bristol Aeroplane Co Ltd (1944) ${ }^{37}$ but in that case also identified three exceptional cases where it would disregard its own previous decision. These are (i) where two Court of Appeal decisions conflict; (ii) if the decision although not expressly overruled conflicts with a later decision of the House of Lords; and (iii) if the earlier decision was given per incuriam (through want of care) however it cannot ignore a decision of the House of Lords on the same basis.

iii- Divisional courts of the High Court have adopted the rule laid down in Young's case although judges sitting at first instance are not bound to follow the decisions of other High Court judges although they tend to do so for the sake of certainty

Judicial precedent is an important source of English law, since an original precedent is one that creates and applies a new rule. However, the later decisions, especially of the higher courts, can have a number of effects upon precedents. In particular, they may be:

a. Reversed: where the decision is reversed in the same case on appeal, the initial decision will cease to have any effect

b. Overruled: where in a later case a higher court decides that the first case was wrongly decided

c. A refusal to follow: this arises when a court, not bound by the decision, cannot overrule it but does not wish to follow it so it simply refuses to follow the previous decision

d. Distinguished: when a previous case is rejected as authority, either because the material facts differ or because the statement of law in the previous case is too narrow to be properly applied to the new set of facts

e. Explained: a judge may seek to interpret a previous decision before applying or distinguishing it, thus the effect of the previous case is varied in the circumstances of the present case.

Finally, complaints against the personal conduct of the judiciary (other than against decisions in proceedings) are handled by the Office for Judicial Complaints. Ultimately, a report is

\footnotetext{
${ }^{35}$ http://www.bailii.org/uk/cases/UKHL/1991/2.html

${ }^{36}$ http://www.bailii.org/uk/cases/UKHL/1977/4.html

${ }^{37}$ https://www.casemine.com/judgement/uk/5a938b3e60d03e5f6b82ba51
} 
made to the Lord Chief Justice and Lord Chancellor. Complaints about the handling of such complaints can be made to the Judicial Appointments and Conduct Ombudsman. ${ }^{38}$

\subsection{A Conclusion of the Mechanisms in the New CPC}

As mentioned above, in order to answer the questions posed in this article-on the need for legal certainty and predictability of decisions-, the New CPC established a system of "precedents", understood and with some decisions that establish a principle and are linked to the previously decided principles. ${ }^{39}$

In this regard, the Code is quite didactic and expletive to announce, in Article 926, that "The courts must standardize their case and keep it stable, fair and consistent." In its paragraphs, the same precepts establish: "§ 1 In the established form and according to the assumptions set out in the bylaws, the courts shall issue statements of summary corresponding to their dominant jurisprudence. $\S 2$. When editing statements of precedent, the courts must abide by the precedent of the factual circumstances that motivated their creation."

Therefore, the mandatory system of precedents and the compliance in the grounds of judicial decisions (art. 489, § 1, VI) were determined, bringing in fact, more security, stability and coherence to the civil justice system, as well as an increased jurisdictional confidence in the Brazilian legal system. ${ }^{40}$

Moreover, another interesting innovation in this direction was the establishment of a microsystem of trial for repetitive cases, able to unify the understanding of the courts as to processes in series containing controversy on the same legal issue.

The Incident Repetitive Demands Resolution (IRDR - art. 976 and the following articles), for example, should be guided, according to Sofia Temer, on three main pillars, namely: equality, which determines the treatment and uniform solution to the same legal issues; legal certainty, predictability and uniformity stamped of judgments; and the effectiveness and speed because of adjudication given within a reasonable time and appropriate manner. ${ }^{41}$

Once the IRDR is established and judged, it will be subject to wide publicity, pursuant to the caput of the Article 976, requiring that the factual and legal grounds that led to the decision are indicated. Thus, as we can see, the intention of the ordinary legislator was to ensure the predictability of judicial decisions, by giving more prominence to already presented legal arguments, making the claimants assured that their case will be judged according to the rationale presented to an identical legal question.

\footnotetext{
${ }^{38}$ The Judiciary within the State: Governance and Cohesion of the Judiciary: Lionel Cohen Lecture 2017, Jerusalem, 15 May 2017 - Lord Thomas of Cwmgiedd. Israel Law Review; Jerusalem Vol. 51, Iss. 1, (Mar 2018): 127-143.).

${ }^{39}$ Também a doutrina fazia observação similar: "Mesmo sem a conotação de ser vinculativa, a jurisprudência mormente em suas formas superlativas - dominante ou sumulada - nunca deixou de exercer uma inegável força persuasiva dentre nós (.....)." (Súmula vinculante e a EC 45/2004). MANCUSO, Rodolfo de Camargo. Súmula vinculante e a EC 45/2004. Teresa Arruda Alvim Wambier et al (coord). Reforma do Judiciário: primeiras reflexões sobre a EC 45/2004. São Paulo: Revista dos Tribunais, 2007, p. 688 - itálicos do original. Após a entrada em vigor do CPC/2015, porque vingou aqueles estudos, participando agora do sistema positivado, tivemos diversos autores comentando os fundamentos comparticipativos, encampada na boa-fé processual e no princípio da cooperação. Para citar alguns: WAMBIER, Teresa Arruda Alvim; CONCEIÇÃO, Maria Lúcia Lins; RIBEIRO, Leonardo Ferres da Silva; MELLO, Rogério Licastro Torres. Primeiros comentários ao novo código de processo civil: artigo por artigo. 1. ed., São Paulo: Editora Revista dos Tribunais, 2015, p. 62. NEVES, Daniel Amorim Assumpção. Direito processual civil. 10. ed., vol. 1 - Salvador: Editora JusPodivm, 2018, p. 204.

${ }^{40}$ CÂMARA, Alexandre Freitas. O novo processo civil brasileiro. 2 ed. São Paulo: Atlas, 2016, p.20.

${ }^{41}$ TEMER, Sofia. Incidente de Resolução de Demandas Repetitivas. São Paulo: Editora JusPodivm, 2016, p. 39.
} 
Regarding the principle of equality, it is right that decisions to disparate resembled situations greatly compromise the equality between the litigants. However, the alluded mechanisms brought by the New CPC are capable, in principle, of protecting the equality of the jurisdictional, insofar as they perform the standardization of the law exacerbated by judicial dispersion, giving equal treatment to legal issues that undergo the same interpretation and application.

Similarly, the equality is directly related to legal certainty, since, when the Judiciary selects a legal interpretation and applies it uniformly to other similar cases, it establishes its understanding on the subject, by ensuring predictability of its operations and, ultimately, the stability of all future legal relationships, because that demonstrates a reliability of postural adjudication.

In this same environment, it establishes the Incident of Assumption of Competence (art. 947), for cases of relevant "question of law" with "great social repercussions," [but] without repetition in multiple processes. ${ }^{42}$ This incident may be brought-the above requirements being present-both in resources, as well as required competency processes originating in the courts and will also be initiated when there is a relevant question of law "regarding what is convenient, preventing or composition of divergence among chambers or divisions of the court." ( $\$ 4$, Art. 947).

According to the first paragraph of the said device, the rapporteur will propose, by default or application by the Public Ministry or the Public Defender, "that the outcome is that the necessary competent process originally tried by a collegial body indicates the regiment." But to do so, the competent collegial body should recognize the presence of public interest in the assumption of competence.

The novelty here, in our view, is what is provided for in the third paragraph of the same article. According to the disposed therein, the judgment is "binding upon all judges and fractional organs unless there is a review of the legal thesis." 43

In the same direction, and with a clear main concern with the performance of the courts, it unifies and establishes up the system (now more rational) of special and extraordinary appeal judgments. Now, Article 1036 states that "Whenever there is multiplicity of extraordinary or special actions on grounds of identical question of law, there will be affectation for judgment in accordance with the provisions of this subsection [arts. 1036-1041], subject to the provisions of the Internal Rules of the Supreme Court and the Superior Court of Justice."

It should be noted also that the new CPC gave greater powers to the rapporteurs in the midst of the courts, also based on the previous system. Thus, the novel diploma disciplined rapporteur is allowed to uphold the resources, in addition to the cases provided for in the former Article 557, Paragraph 1-A, which provided the opportunity to follow up the action whether the contested decision was in clear confrontation with summary or dominant ruling in the Supreme Federal Court or the superior court.

From what is disciplined in the current Article 932, it is the rapporteur that must allow the appeal in which the contested decision is at odds with the judgment of the Federal Court or Superior Court of Justice on the trial of repetitive cases; understanding signed in resolution incident repetitive demands or assumption of competence. Moreover, it is possible to dismiss the action that is contrary to the judgment of the Supreme Federal Court's assumption of competence.

\footnotetext{
${ }^{42}$ Daí sua distinção para o IRDR, que exige, necessariamente, a repetição de processos envolvendo a mesma questão jurídica.

${ }^{43}$ MEDINA, José Miguel Garcia. Novo Código de Processo Civil comentado. São Paulo: Revista dos Tribunais, 2016, p. 1353.
} 
That said, based only on some of the devices brought in by the New CPC, it is possible to identify the overriding importance of protecting the integrity of the Brazilian legal system, as a result of the need to protect the equality and legal certainty, here understood as a sum of stability and predictability of the judicial decision method.

All this is in line with the new constitutional process model established by the dynamics of the New CPC and allowing, ultimately indeed, an environment suitable for the development and improvement of questions posed by society.

Therefore, it is possible to conclude that the New CPC has taken an important step to create a space with a greater degree of stability, giving the productive activity a business environment more permeable to legal certainty and predictability. Indeed, it was the intention of the New CPC, through its new regulations, which with respect to the previous system, the supervisory microsystem of repetitive judgments and predictability of judicial decisions sought to provide a more favorable common place to new investments, increased productivity, job creation, economic growth and hence to social growth.

\section{FINAL CONSIDERATIONS}

The judicial activity, which is a constitutionally assigned role to the courts, is constantly the target of concerns and debates that have the scope of promoting the desired effectiveness of judicial protection, which is permeated by delays and processual congestion due to the high rates of litigation.

Among the purposes of this article, it was revealed that the lack of uniformity and predictability of judicial decisions is as harmful as the delay in the procedure, since in addition to generating too much uncertainty and legal uncertainty, it fosters disproportionate access to the judicial and disregards the constitutional principles, representing a dangerous affront to the democratic rule of law.

From the perspective of constitutional changes to the civil procedures, this study sought to outline the situation of judgments and Brazilian courts, in view of the litigation crisis plaguing the judiciary, by stressing the importance of principled matrix on which to settle the procedural relationship under penalty of relegating the social fabric to helplessness and discrediting the justice system.

From the ideals of the New CPC, it is essential that the process is steady in the light of principles, values and guarantees, establishing itself as a cooperative, dialectical, effective and efficient instrument in protecting the rights of the litigants. To the same extent, it is imperative that access to justice and equality is guaranteed in the decision-making process of the Courts, so that equal decisions are reached for identical cases, thus promoting an environment that urges for legal certainty, trust, protection and predictability of court decisions.

According to what the New CPC dictates, the above-mentioned mechanisms should always be outlined in favor of uniform treatment of homeland cases, since the Brazilian judiciary, wrapped in a grave chaotic frame of jurisprudential dispersion, requires court decisions that effectively solve the dispute, allowing the coexistence of a peaceful society.

Thus, the new civil procedural law embraced courageously the theory of precedent, establishing other mechanisms outlined here, which together tend to give greater effect to principles and guarantees such as equality, legal certainty and legitimate confidence in the judiciary.

The debate about the economic impact of judicial decisions is nothing new, which is why the attempt to respect the principle of legal certainty will only bring benefits, such as the proper 
administration of justice and the stability of social relations, the main scopes of the State democratic rights that need to be pursued constantly.

In line with the constitutional civil procedure, the instruments listed here aim to bring objectivity and uniformity of law, also conspicuous by predictability of legal positions, shielding citizens from possible changes in understanding and, ultimately promoting coherence of the legal system and greater efficiency of the judiciary.

So it can be concluded that the New CPC regulations shown a priori are able to meet the social aspirations for a process that is more just, equitable, secure and stable. That is why it is necessary that the procedural system offer new responses to situations that are presented, under penalty of becoming truly obsolete and ineffective. Uncontrolled and excessive litigation and casedispersion are unavoidable situations that tend to deteriorate facing the State policy inertia.

Therefore, the aim of the New CPC was largely to bring light to the disorder operated by a deformed and unstable jurisprudence, facing the issue of multiplicity and seeking to pacify conflicts and mass controversy for the sake of cohesion, unity, integrity, stability and effectiveness of the Brazilian legal system. Ultimately, this scenario also implies serious violation of the principle of legality, in which the laws are interpreted differently by the courts.

With its term, the challenges of the new law are not few; there is a long way in this journey to standardize the country's jurisprudence. The New CPC and its procedural mechanisms promise to give a new impetus to the current scenario, providing litigants with a peaceful environment based on the predictability of vectors, stability, equality and legal certainty.

\section{REFERENCES}

ARRUDA ALVIM, José Manoel de. Novo Contencioso Cível no CPC/2015. São Paulo: Revista dos Tribunais, 2016.

BARBOSA, Andrea Carla; CANTODARIO, Diego Martinez Fervenza. O incidente de resolução de demandas repetitivas no projeto de Código de Processo Civil: apontamentos iniciais. O Novo Processo Civil Brasileiro (direito em Expectativa): reflexões acerca do projeto do novo Código de Processo Civil. Coord. Luiz Fux. Rio de Janeiro: Forense, 2011, pp. 448-449.

BARBOSA MOREIRA, José Carlos. A motivação das decisões judiciais como garantia inerente ao Estado de Direito. Temas de Direito Processual. São Paulo: Saraiva, 1988.

BARROSO, Luís Roberto. Curso de direito constitucional contemporâneo: os conceitos fundamentais e a construção do novo modelo. São Paulo, Saraiva, 2009.

BATISTA, Bárbara Gomes Lupetti. Reflexões sobre o dever de fundamentação das decisões judiciais e a imparcialidade judicial: 'o que falar quer dizer' e o que não dizer quer falar? Amazon's Research and Environmental Law, Rondônia, vol. 3, n. 3, 2015, pp.

107-130. Disponível em:

DOI: http://dx.doi.org/10.14690/2317-8442.2015v33169. Acesso em 02.07.2017.

BOGDANOR, Parliament and the Judiciary: The Problem of Accountability, (Third Sunningdale Accountability Lecture 2006); Le Sueur in Independence, Accountability and the Judiciary (BIICL 2006), eds Andeanas and Fairgrieve, 49-50. 
BONICIO, Marcelo José Magalhães. Princípios do processo no novo Código de Processo Civil. São Paulo: Saraiva, 2016.

BUENO, Cassio Scarpinella. Novo Código de Processo Civil Anotado. 3 ed. São Paulo: Saraiva, 2017.

CÂMARA, Alexandre Freitas. O novo processo civil brasileiro. 2 ed. São Paulo: Atlas, 2016.

COHEN, Lionel. The Judiciary within the State: Governance and Cohesion of the Judiciary. Lecture 2017, Jerusalem, 15 May 2017 - Lord Thomas of Cwmgiedd. Israel Law Review; Jerusalem Vol. 51, Iss. 1, (Mar 2018): 127-143.).

CONSELHO NACIONAL DE JUSTIÇA. Relatório Justiça em Números 2016: ano-base 2016. Brasília: CNJ, 2016.

CONSELHO NACIONAL DE JUSTIÇA. 100 maiores litigantes 2012. Brasília: CNJ, 2012.

COUTO, Mônica Bonetti; MEYER-PFLUG; Samantha Meyer. Processo Civil e Constituição: uma (Re) aproximação necessária. Processo e Jurisdição. Organização: CONPEDI/UFF. Coordenadores: Vladmir Oliveira da Silveira; Aires José Rover. Florianópolis, FUNJAB, 2012, pp. 411-433. <http://www.publicadireito.com.br/artigos/?cod=173f0f6bb0ee97cf>. Acesso em 05.05.2017.

DONIZETTI, Elpídio. Constitucionalização do direito processual civil. Disponível em: $<$ http://atualidadesdodireito.com.br/elpidionunes/2012/04/11/expressaconstitucionalizacao-dodireito-processual-civil-positivacao-do-\%E2\%80\%9Ctotalitarismoconstitucional\%E2\%80\%9D/> Acesso em: 16.03.2017.

FLEXA, Alexandre; MACEDO, Daniel; BASTOS, Fabrício. Novo Código de Processo Civil: temas inéditos, mudanças e supressões - 2. Ed., rev. Ampl. E atual. Salvador: JusPODIVM, 2016.

GAGELER, Stephen. Book Reviews: Controlling Administrative Power: An Historical Comparison - The Cambridge Law Journal; Cambridge Vol. 76, Iss. 2, (Jul 2017).

GUERRA FILHO, Willis Santiago. Processo Constitucional e Direitos Fundamentais. 2. ed. São Paulo: Celso Bastos Editor, 2001.

MANCUSO, Rodolfo de Camargo. Súmula vinculante e a EC 45/2004. Teresa Arruda Alvim Wambier et al (coord). Reforma do Judiciário: primeiras reflexões sobre a EC 45/2004. São Paulo: Revista dos Tribunais, 2007.

MEDINA, José Miguel Garcia. Novo Código de Processo Civil comentado. São Paulo: Revista dos Tribunais, 2016.

NEVES, Daniel Amorim Assumpção. Direito processual civil. 10. ed., vol. 1 - Salvador: Editora JusPodivm, 2018. 
NERY JUNIOR, Nelson; NERY, Rosa Maria de Andrade. Comentários ao Código de Processo Civil - Novo CPC - Lei 13.105/2015. São Paulo: Revista dos Tribunais, 2015.

NERY JUNIOR, Nelson; NERY, Rosa Maria de Andrade. Princípios do processo na Constituição Federal. 9. ed. São Paulo: Revista dos Tribunais.

PONTIFÍCIA UNIVERSIDADE CATÓLICA. Demandas judiciais e morosidade da Justiça Civil - Relatório Final (PUC-RS), Edital CNJ 01/2009, Porto Alegre, dezembro/2010.

SANTOS, Raphael de Souza Almeida. Entre a técnica e a efetividade: o ativismo judicial como instrumento de garantia dos direitos fundamentais. Amazon's Research and Environmental Law, Rondônia, vol. 1, n. 1, 2013, pp. 76-94. Disponível em: DOI:

http://dx.doi.org/10.14690/2317-8442.2013v11101. Acesso em 02.07.2017.

SENADO FEDERAL. Anteprojeto do Novo Código de Processo Civil. Disponível em: <https://www.senado.gov.br/senado/novocpc/pdf/Anteprojeto.pdf> Acesso em 25.08.17.

STRECK, Lênio Luiz. Verdade e Consenso, 4. ed. 2. tiragem. São Paulo: Saraiva, 2012.

SENDRA, José Vicente Gimeno . El derecho a un proceso sin dilaciones indebidas. Madri: Ed. CGPJ, n. especial I, 1986.

TEMER, Sofia. Incidente de Resolução de Demandas Repetitivas. São Paulo: Editora JusPodivm, 2016.

THEODORO JÚNIOR, Humberto. Onda reformista do Direito Positivo e suas implicações com o princípio da segurança jurídica. Revista Brasileira de Estudos Políticos, nº 89, jan-jun 2004.

THEODORO JÚNIOR, Humberto; NUNES, Dierle; BAHIA, Alexandre Melo Franco; PEDRON, Flávio Q. Novo CPC: fundamentos e sistematização. Rio de Janeiro, Forense, 2016.

WAMBIER, Teresa Arruda Alvim. Estabilidade e adaptabilidade como objetivos do direito: civil e common law. Revista de Processo. v. 172, pp. 121-150. São Paulo: Revista dos Tribunais, junho/2009.

WAMBIER, Teresa Arruda Alvim; CONCEIÇÃO, Maria Lúcia Lins; RIBEIRO, Leonardo Ferres da Silva; MELLO, Rogério Licastro Torres. Primeiros comentários ao novo código de processo civil: artigo por artigo. 1. ed., São Paulo: Editora Revista dos Tribunais, 2015.

WAMBIER, Teresa Arruda Alvim; et al. Primeiros Comentários ao Novo Código de Processo Civil. 2. ed. São Paulo: Editora Revista dos Tribunais, 2016.

WAMBIER, Teresa Arruda Alvim; DANTAS, Bruno. Recurso especial, recurso extraordinário e a nova função dos tribunais superiores no direito brasileiro - de acordo com o CPC de 2015 e a Lei 13.256/2016, 3. ed. São Paulo: Revista dos Tribunais, 2016. 


\section{JURISPRUDENCE}

https://www.judiciary.uk/wp-content/uploads/JCO/Documents/Consultations/accountability.pdf

The Responsibilities of Resident Judges and Designated Civil and Family Judges https://www.judiciary.uk/about-the-judiciary/the-judiciary-the-government-and-theconstitution/how-the-judiciary-is-governed/leadership-responsibilities/

Murphy v Brentwood District Council [1991] UKHL 2 (26 July 1990) http://www.bailii.org/uk/cases/UKHL/1991/2.html

Anns v Merton London Borough Council [1977] UKHL 4 (12 May 1977) http://www.bailii.org/uk/cases/UKHL/1977/4.html

Young v. Bristol Aeroplane Co Ltd [1944] KB 718 CA

https://www.casemine.com/judgement/uk/5a938b3e60d03e5f6b82ba51 